\title{
ノズル出ロ近傍の通水穴によるキャビテーション噴流の加エ能力向上
}

\author{
上坂 洋雄*1, 祖山 均 ${ }^{* 2}$
}

\section{Enhancement of an aggressive intensity of a cavitating jet by water flow holes near nozzle outlet}

\author{
Hirokazu KAMISAKA $^{* 1}$ and Hitoshi SOYAMA ${ }^{* 2}$ \\ ${ }^{*}$ Sugino Machine Limited \\ 2880 Kuriyama, Namerikawa-shi, Toyama 936-8577, Japan \\ ${ }^{* 2}$ Department of Finemechanics, Tohoku University \\ 6-6-01 Aoba, Aramaki, Aoba-ku, Sendai 980-8579, Japan
}

Received: 9 July 2019; Revised: 29 August 2019; Accepted: 9 October 2019

\begin{abstract}
The cavitation cloud generated by submerged high-speed water jet has periodicity. The periodicity is provided by alternately repeating the bubbles generation and shedding process and cavitation nucleus filling process. Therefore, the construction of the filling process allows control of the shedding frequency of the cavitation clouds and may improve the aggressive intensity of the cavitating jet. In this paper, the water flow holes were provided at the nozzle throat outlet in order to form a stable and continuous filling flow. The aggressive intensity of this nozzle was compared by the mass loss of JIS A1050P. In addition, the cavitating jet was observed with a high speed video camera to confirm the characteristics of the jet. As a result, the mass loss per unit area increased as the diameter of the water flow holes increased. It is speculated that the enhanced flow around the cavitating jet due to the action of the water flow holes caused the increase in the damming pressure on the specimen. The increase in damming pressure increased the impact density and collapse impact force of the cavitation bubbles. Moreover, the large water flow holes resulted in stabilization of the shedding frequency of the cavitation clouds and growth scale. It may be a factor that the stable supply of cavitation nuclei to the cavitation main generation field was realized. However, since the water flow holes did not change the shedding frequency significantly, it is considered that the influence of the frequency on the aggressive intensity is small in this experiment.
\end{abstract}

Keywords : Nozzle, Cavitating jet, Cloud, Shedding frequency, Erosion, High-speed observation

\section{1. 緒言}

水中で高速水噴流を噴射する際に生じるキャビテーション気泡の崩壊衝撃力を利用したピーニング加工により， 圧縮応力の付与やそれに伴う疲労強度の向上が実証されている（祖山他，1996），(平野他，1996），(Soyama et al., 2002)，（Soyama, 2019）。キャビテーション気泡雲を伴った高速水噴流，いわゆるキャビテーション噴流の加工能 力には, ノズル形状やノズルスロート径, 噴射圧力, キャビテーション数などが影響する (Soyama, 2017). また, これらパラメータは，キャビテーション気泡雲の放出周波数（Soyama et al., 1995）にも影響を及ぼすため，キャ ビテーション噴流の加工能力と気泡雲の放出周波数には密接な関係があると考えられる.

キャビテーション気泡雲の放出周波数特性に関わる研究として，祖山らは，ノズルスロート出口に円筒空間を 有するノズルを用いた実験により, 円筒空間の大きさによって気泡雲の放出周波数が変化することを示している

（祖山，西澤，2009）。その際，キャビテーション気泡雲の画像解析で得られた放出周波数のパワースペクトル密 度と, 純アルミニウムの壊食試験結果から，パワースペクトルの卓越周波数が鋭敏かつ高周波数側であるほど, 壞食量が増加傾向を示すことを報告している. Nishimura らは，同様のノズルを用いた実験により，放出周波数が 噴射圧力の平方根に比例し，ノズルスロート径に反比例することを示している（Nishimura et al., 2012）. Kamisaka

No.19-00280 [DOI:10.1299/transjsme.19-00280], J-STAGE Advance Publication date : 21 October, 2019

*1 正員，(株) スギノマシン（广936-8577 富山県滑川市栗山 2880）

*2 2 正員, フェロー, 東北大学大学院 工学研究科（一980-8579 宮城県仙台市青葉区荒巻字青葉 6-6-01）

E-mail of corresponding author: h.kamisaka@sugino.com 
らは，自由噴流と衝突噴流とで気泡雲の放出周波数が異なる傾向を示すことから，気泡雲崩壊時に生じる圧力波 の伝播が放出周波数に影響する可能性を示唆している（Kamisaka and Soyama, 2018）.

上記，キャビテーション気泡雲放出の周期性は，気泡雲の生成・放出プロセスと，次なる気泡雲の生成に不足 している，キャビテーション核（加藤，2016）を含んだ流れの充填プロセスとを交互に繰り返すことに起因する と考えられる（充填プロセス中に生じるノズルスロート出口方向への流れを以下, 充填流と記載する). 出口がホ ーン形状のノズルを用いた Sato らの研究では, 気泡雲の放出後, 下流から上流方向の充填流が発生し, ノズルス ロート出口に充填流が到達直後, 次なる気泡雲が生成・放出される様相が観察されている（Sato et al., 2013）。浦 らは，同様のノズルを用いて，ホーン部の拡大角が大きいほど気泡雲の放出周期および充填流の発生周期が短い ことを報告している (浦他, 2018). したがって, 上記充填プロセスの構築により, 気泡雲の放出周波数を制御し, キャビテーション噴流の加工能力を向上できる可能性がある.

本報では，キャビテーション気泡の主生成場であるノズルスロート出口への, 安定かつ連続的な充填プロセス の構築を目的とし, キャビテーション噴流ノズルのノズルスロート出口に通水穴を設けた. この通水穴の加工能 力への影響を明らかにするために， JIS A1050P の壊食量を評価指標とし，通水穴の無いノズルと通水穴径が異な る 2 種類のノズルの合計 3 種類のノズルを用いて実験を行った．また，上記ノズルのキャビテーション気泡雲放 出の周波数特性を確認寸るために, 高速度ビデオカメラで撮影したキャビテーション噴流の画像解析を行った.

\section{2. 実験装置および方法}

\section{$2 \cdot 1$ キャビテーション噴流装置}

実験装置の概略を図 1 に示寸. 実験装置は, 最大吐出圧力 $70 \mathrm{MPa}$ の 3 連プランジャポンプと, キャビテーシ ヨン噴流で試験片を処理するタンク A，プランジャポンプヘの供給水を貯めるタンク B から構成される. 水は地 下水を使用した。蛍光式溶存酸素計（HQ30d，HACH）で測定した，実験中のタンク A における水温および溶存 酸素量は $24.0 \sim 29.0^{\circ} \mathrm{C}, 5.6 \sim 6.6 \mathrm{mg} / \mathrm{L}$ であった. タンク A では, 噴射流量分だけ水位が上昇するため, タンク底 から適量排水することで水位を一定に保った．また，水面からの空気の巻き込みを防止するために，タンク A の 水面に板状の発泡ポリエチレン材を浮かべた.これにより, 実験中の水面からの空気の巻き込みは皆無であった.

\section{$2 \cdot 2$ キャビテーション噴流ノズル}

図 2 にノズルの形状を示す.ノズルは, ノズルプレート出口の円筒空間の最適化（Soyama, 2011）と, キャビ テータとガイドパイプの装着（Soyama, 2014）によって加工能力の向上が図られている.ノズルの各パラメータ を表 1 に示寸. 各パラメータの值は既報（Soyama,2014）を参考にした. 1 章で述べたように，キャビテーション 核を含む流れの安定かつ連続的な供給を目的として，ノズルプレート出口に通水穴を設けた．通水穴は，ノズル 中心軸との直交断面において, 45 毎に計 8 個存在する. 加工能力に対する通水穴径 $d_{h}$ の影響を調べるために, 通水穴無し, $d_{h}=2.0 \mathrm{~mm}, d_{h}=3.5 \mathrm{~mm}$ の 3 種類のノズルで実験を行った。噴射圧力は, 既報（上坂, 祖山, 2018）

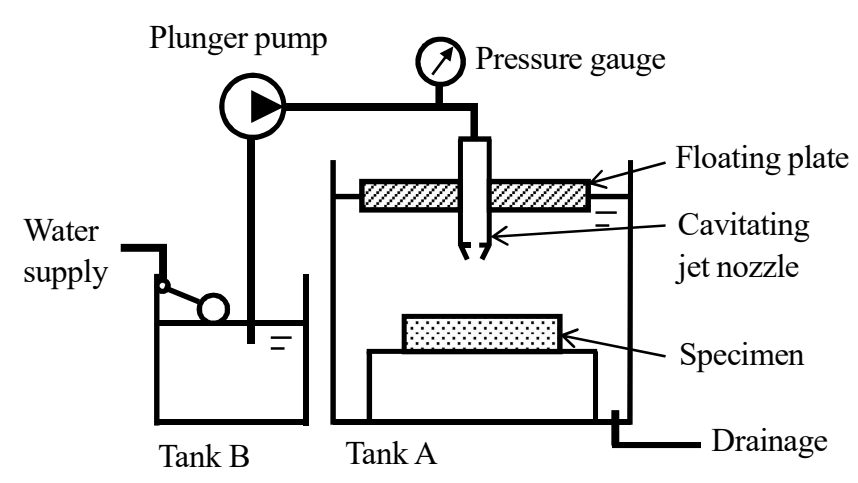

Fig. 1 Schematic diagram of cavitating jet system.

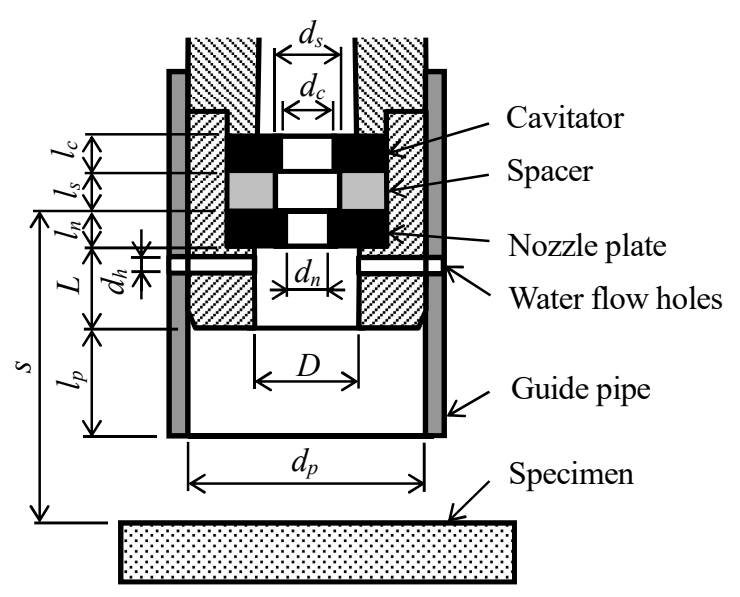

Fig. 2 Geometry of nozzle for cavitating jet. 
Table 1 Geometry of nozzle for cavitating jet.

\begin{tabular}{lcc}
\hline \hline \multicolumn{1}{c}{ Parameter } & Symbol & Value $[\mathrm{mm}]$ \\
\hline Inner diameter of nozzle plate & $d_{n}$ & 2 \\
\hline Inner diameter of cavitator & $d_{c}$ & 3 \\
\hline Inner diameter of spacer & $d_{s}$ & 6 \\
\hline Inner diameter of guide pipe & $d_{p}$ & 44 \\
\hline Inner diameter of cylindrical space & $D$ & 16 \\
\hline Length of nozzle plate & $l_{n}$ & 6 \\
\hline Length of cavitator & $l_{c}$ & 6 \\
\hline Length of spacer & $l_{s}$ & 6 \\
\hline Length of guide pipe & $l_{p}$ & 46 \\
\hline Length of cylindrical space & $L$ & 16 \\
\hline
\end{tabular}

にて, 最大の加工能力が得られた $40 \mathrm{MPa}$ に設定した. ノズルプレート入口の角ではく離後の流れは, 縮流によ ってノズルプレート内壁に再付着しないと考えられる（熊谷, 祖山，2016）ため, スタンドオフ距離 $s$ はノズル プレートの上流側角部から試験片の表面までの距離と定義した.

\section{$2 \cdot 3$ キャビテーション噴流の加工能力の評価方法}

キャビテーション噴流の加工能力を JIS A1050P の壊食量で評価した. 試験片の寸法は, 長さ $150 \mathrm{~mm}$, 幅 150 $\mathrm{mm}$, 厚さ 5〜 $10 \mathrm{~mm}$ とした.ノズルを試験片に対して垂直に固定し, キャビテーション噴流が試験片の中央に当 たるように一定時間噴射した. 周知のように, 単位時間当たりの壊食量は累積噴射時間とともに変化し, 潜伏期, 加速期，最大壊食期，減速期を経る（ASTM G134-17,2017）。壊食量の比較には，潜伏期を越えるだけ噴射時間を 設け，壊食を進行させる必要がある．著者らは予備実験により，15 min 以上の噴射時間が望ましいと判断し，本 報での噴射時間を $15 \min$ に設定した.

\section{$2 \cdot 4$ キャビテーション噴流の高速度ビデオカメラ観察}

キャビテーション気泡雲の放出周波数を調べるために, 高速度ビデオカメラ (Photron, FASTCAM Mini AX200) で撮影したキャビテーション噴流の画像輝度を高速フーリエ変換（FFT） し解析した．気泡雲の基本的な周波数 特性を把握するために, 試験片を設置していない状態の自由噴流のみを撮影対象とした. 1 章で述べたように, 既報（Kamisaka and Soyama, 2018）では，自由噴流と衝突噴流における気泡雲の放出周波数が異なる傾向を示すこ とが報告されている。しかし，既報でのそれら放出周波数に大差がないことから，本報では，自由噴流と衝突噴 流の気泡雲の放出周波数を定性的に同一と見なし, 後の評価を実施した. ビデオカメラの撮影速度を 10,000 fps と したため, サンプリング周期は $0.1 \mathrm{~ms}$ となる. 光源には, メタルハライドランプ（協和, MID-25FC) を使用し た．噴流に対し，ビデオカメラと同じ位置に光源を配置したため，画像上で気泡雲は白く写る．周波数解析で用 いた画像のサイズは，噴流と平行方向に 32 ピクセル，噴流と直交方向に 100 ピクセルで，これは $38.4 \times 120 \mathrm{~mm}$ に相当する.

\section{3. 実験結果および考察}

\section{$3 \cdot 1$ 壊食試験}

JIS A1050P の壊食試験で得られた，スタンドオフ距離 $s$ と壊食量 $\Delta m$ の関係を図 3 に示す. 通水穴径 $d_{h}$ が大き いほど, 壊食量の最大值 $\Delta m_{\text {max }}$ が大きくなる傾向がある. 通水穴の無いノズルでの $\Delta m_{\max }$ を基準とすると, $\Delta m_{\max }$ の 増加量は, $d_{h}=2.0 \mathrm{~mm}$ では $16.0 \%, d_{h}=3.5 \mathrm{~mm}$ では $34.1 \%$ となっている. $\Delta m_{\max }$ をとるスタンドオフ距離, すな わち最適スタンドオフ距離 $s_{\text {opt }}$ は, 各通水穴条件で同一の $150 \mathrm{~mm}$ であった. 


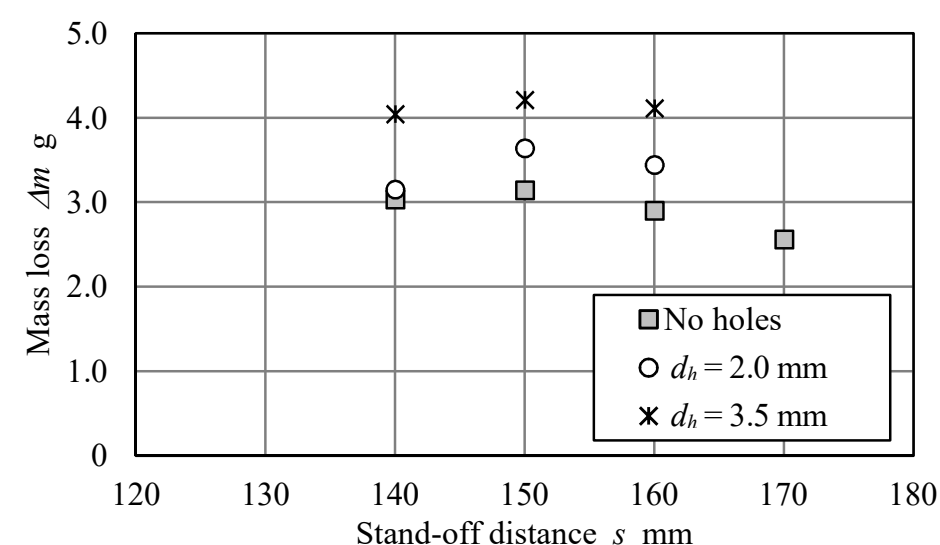

Fig. 3 Erosion test result using each nozzles with water flow holes. The maximum value of mass loss $\Delta m_{\max }$ increases as the diameter of the water flow holes $d_{h}$ increased. Even if $d_{h}$ increases, the stand-off distance of $\Delta m_{\max }$, i. e. optimum standoff distance $s_{\text {opt }}$ was the same at $150 \mathrm{~mm}$.

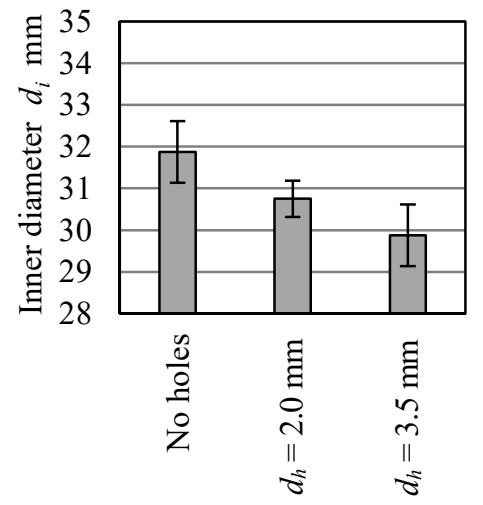

(a) Inner diametr $d_{i}$

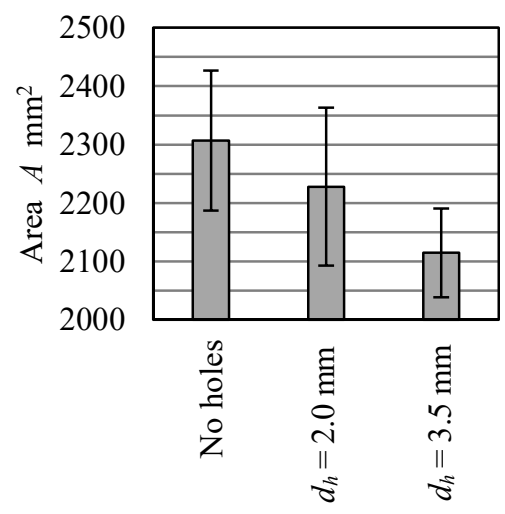

(c) Erosion area $A$

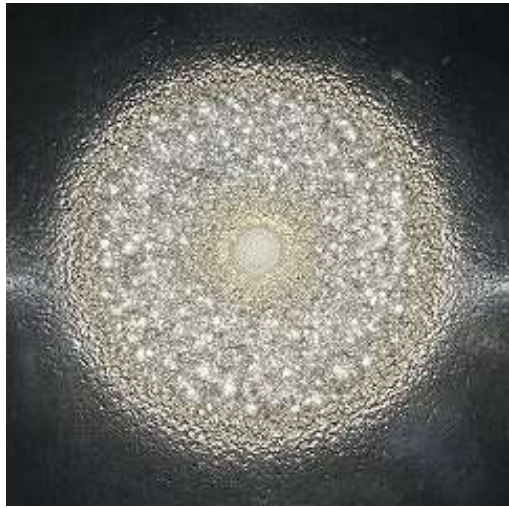

Fig. 4 Erosion area after erosion test for 15 minutes. The erosion area has a central erosion area by the jet core and an annular erosion area by cavitation.

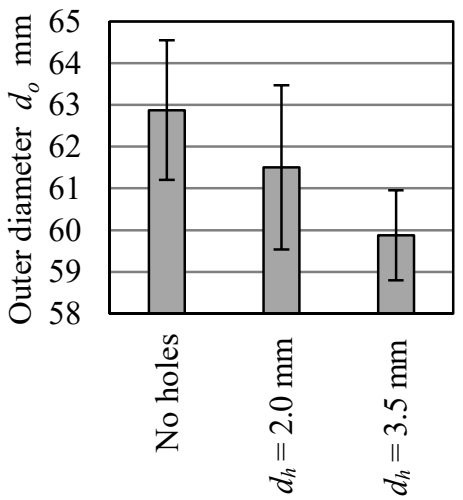

(b) Outer diametr $d_{o}$

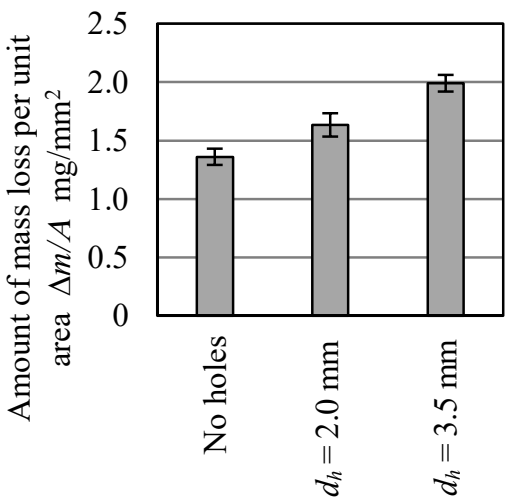

(d) Amount of mass loss per unit area $\Delta m / A$

Fig. 5 Parameters of annular erosion area formed by cavitation. Looking at (a), (b) and (c), the larger the diameter of the water flow holes, the smaller the inner diameter $d_{i}$, the outer diameter $d_{o}$ and the area $A$ of the annular erosion area. This means that cavitation bubbles collapsed at the center of the jet. It is presumed that the flow from the water flow holes to the nozzle plate outlet enhanced the accompanying flow around the cavitating jet, and the damming pressure on the specimen increased. Looking at (d), as the water flow holes diameter is larger, the mass loss per unit area $\Delta m / A$ tends to increase. This factor includes the increase of the collapse impact force of the cavitation bubbles and the increase of the impact frequency to the same place on the specimen. It is possible that the increase of the damming pressure on the specimen due to the strengthening of the accompanying flow resulted in the increase of the collapse impact force of the cavitation bubbles. The decrease in erosion area means that the impact density of cavitation bubbles is increased. 
図 4 に, 15 min の壊食試験後の JIS A1050P 試験片の様相を示寸．既報（Soyama, 2011）のように，噴流コアに よる中央の壊食領域と, キャビテーションによる環状の壊食領域が存在している. 最適スタンドオフ距離 $s_{o p t}=$ $150 \mathrm{~mm}$ で処理した試験片において, 主壊食領域である環状部の内径 $d_{i}$ と外径 $d_{o}$, 面積 $A, \Delta m_{\max }$ を $A$ で除して得 られる単位面積当たりの壊食量 $\Delta m_{\max } / A$ を図 5 に示す. 内径 $d_{i}$ と外径 $d_{o}$ の測定にあたり, レーザ変位計での測定 を試みたが，正確な変位データの取得ができなかったため, 試験片表面からの高さを $0.5 \mathrm{~mm}$ に調整したハイト ゲージを用いて, キャビテーション気泡の崩壊衝撃力によって生じた打痕周りの盛り上がりとハイトゲージが接 触する箇所を壊食領域の境界として判定した. 境界判定後の内径 $d_{i}$ と外径 $d_{o}$ は, 金属製直尺 $(150 \mathrm{~mm}, 1$ 級）を 用いて 45 毎に角度を変えて測定した， 4 方向の平均值とした．面積 $A$ は，内径 $d_{i}$ と外径 $d_{o}$ から算出した.

図 5(a), (b), (c)からわかるように, 径の大きな通水穴を有するノズルほど, 環状壊食痕の内径 $d_{i}$ と外径 $d_{o}$, 面 積 $A$ が小さい. 環状壊食痕の縮小は, 噴流のより中央でキャビテーション気泡が崩壊したことを意味している. この要因として, 試験片上のせき止め圧の上昇が挙げられる.ノズル噴射のエゼクタ効果により, 通水穴からノ ズル内へ流入し, キャビテーション噴流に随伴する流れが形成された結果, 噴流衝突面上のせき止め圧が上昇し たと推測する.

図 5 (d)は，単位面積当たりの壞食量 $\Delta m_{\max } A$ を示している. 通水穴径が大きなノズルほど, 大きな $\Delta m_{\max } / A$ が 得られる傾向がある. この要因として, 図 $5(\mathrm{c})$ に示した壊食面積の縮小に伴い衝撃密度が増加した結果, 潜伏期 が短期化したことが考えられる. また, 上述のように, 通水穴を有するノズルでは, 随伴流の強化により試験片 上のせき止め圧が上昇し得ることから，キャビテーション気泡の崩壊衝撃力が増大している可能性がある. 通水 穴の作用により, 安定かつ連続的な充填流が形成された結果, キャビテーション気泡雲の放出周波数が高周波数 化し，単位時間当たりに試験片上で崩壊するキャビテーション気泡数が増加した可能性もある.

\section{$3 \cdot 2$ キャビテーション気泡雲の放出周波数}

キャビテーション気泡雲の加工能力に関わっている気泡雲の放出周波数を調べるために, 試験片を設置してい ない状態のキャビテーション噴流を高速度ビデオカメラで撮影した．図 6 に, 撮影したキャビテーション噴流の

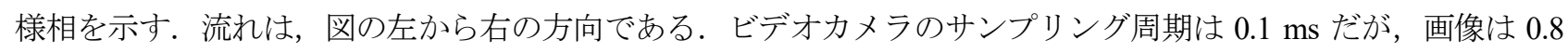
$\mathrm{ms}$ 毎に表示している. 図 6 (a)〜(c)の全条件において, 画像左端に写るガイドパイプから, おおよそ $t=0,4.0$, 8.8, $12.8 \mathrm{~ms}$ で気泡雲の放出が開始される様子が確認できる. したがって, 気泡雲の放出周波数 $f_{\text {shedd }}$ は 200〜 250 $\mathrm{Hz}$ 程度と推定できる. 気泡雲の大きさに着目寸ると, 図 6(a)の通水穴の無いノズルでは, 成長する気泡雲の大き さが比較的不均一に見える.

約 $0.4 \mathrm{~s}$ 間の画像輝度の周波数解析で得られたパワースペクトル密度を図 7 に示寸. 周波数分解能は約 $2.4 \mathrm{~Hz}$ である. 気泡雲の放出周波数を概算するために， 3 点の移動平均を適用した，一例として，最適スタンドオフ距 離 $S_{\text {opt }}$ を含んだ画像解析範囲 $s=120 \sim 158.4 \mathrm{~mm}$ のものを示している. 各通水穴条件の縦軸は同一スケールであ る. 通水穴の無いノズルおよび通水穴径 $d_{h}=2.0 \mathrm{~mm}$ のノズルでは, 卓越周波数が不明瞭であるのに対し, 通水穴 径 $d_{h}=3.5 \mathrm{~mm}$ のノズルでは, 約 $230 \mathrm{~Hz}$ に卓越周波数が確認できる.

図 8 に, 各スタンドオフ距離でのパワースペクトル密度から得られた卓越周波数 $f_{d}$ を示寸. 周波数解析で用い た長さ $38.4 \mathrm{~mm}$ の画像の中央值をスタンドオフ距離 $s$ としてプロットしている. 卓越周波数 $f_{d}$ は, パワースペク トル密度が極大を示寸周波数とした. $s<300 \mathrm{~mm}$ の範囲では, 多少分散したプロットは見られるが，通水穴の無 いノズルでは $f_{d}=222.2 \mathrm{~Hz}$ で, $d_{h}=2.0 \mathrm{~mm}$ のノズルでは $f_{d}=239.8 \mathrm{~Hz}$ で, $d_{h}=3.5 \mathrm{~mm}$ のノズルでは $f_{d}=231.9 \mathrm{~Hz}$ で, それぞれ卓越周波数が安定している. これは, キャビテーション気泡雲の放出周波数 $f_{\text {shedd }}$ を表しており, 図 6 で示した周波数とおおよそ一致する. 通水穴の無いノズルの $f_{\text {shedd }}$ を基準とすると, $d_{h}=2.0 \mathrm{~mm}$ のノズルでは $7.7 \%, d_{h}=3.5 \mathrm{~mm}$ のノズルでは $4.4 \%$, 放出周波数が増加している. これに対し， $3 \cdot 1$ 項で述べたように, 通水 穴の無いノズルを基準とした $\Delta m_{\max }$ の増加率は, $d_{h}=2.0 \mathrm{~mm}$ では $16.0 \%, d_{h}=3.5 \mathrm{~mm}$ では $34.1 \%$ \%ある. $\Delta m_{\max }$ の増加率と比較して $f_{\text {shedd }}$ の増加率が小さいため, 壊食量の増大は, $f_{\text {shedd }}$ の高周波数化が支配因子となってもたら されたものではないと判断できる. $s>300 \mathrm{~mm}$ では, 通水穴条件によっては, $f_{d}$ が $120 \mathrm{~Hz}$ 以下に激減している. これは，気泡雲が $s>300 \mathrm{~mm}$ に到達し難いことを示している.

図 9 は, 図 8 から得られた各ノズルの放出周波数 $f_{\text {shedd }}$ におけるパワースペクトル密度である. パワースペクト ル密度が大きいほど, 気泡雲の放出周波数が安定していることを意味する. 周波数解析を実施した大部分のスタ 


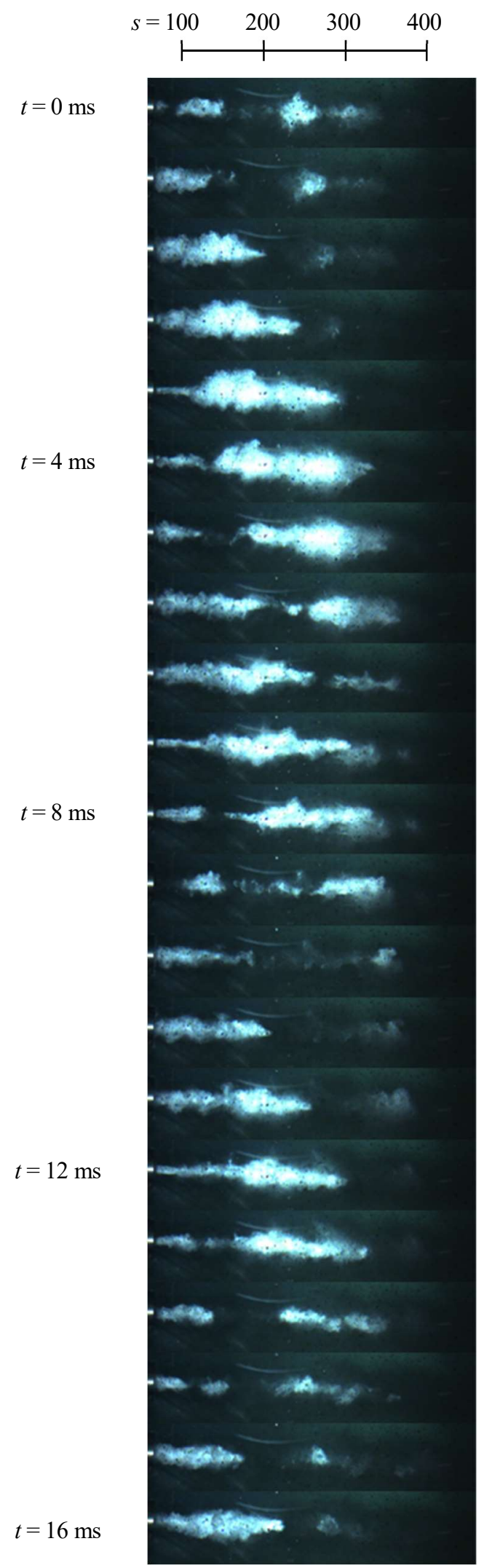

(a) No holes

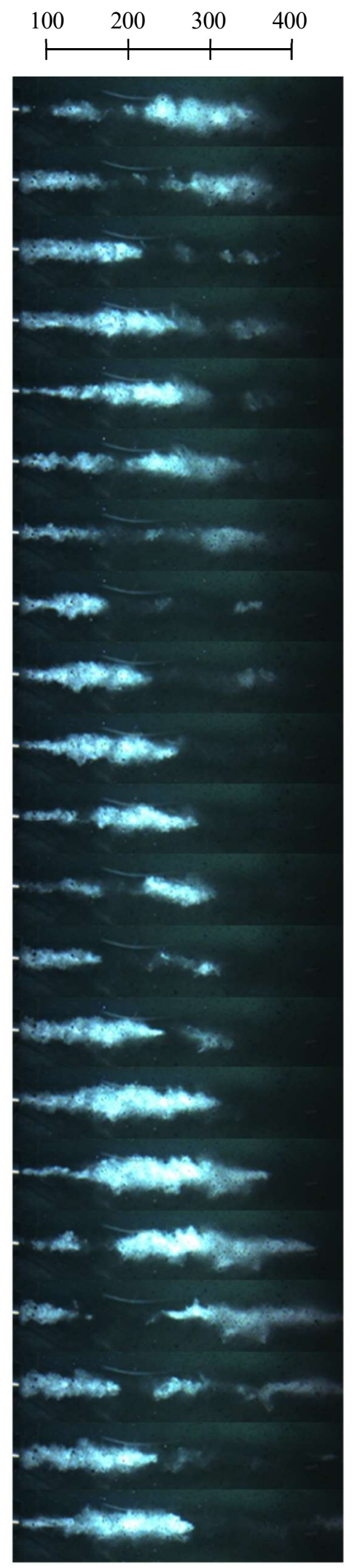

(b) $d_{h}=2.0 \mathrm{~mm}$
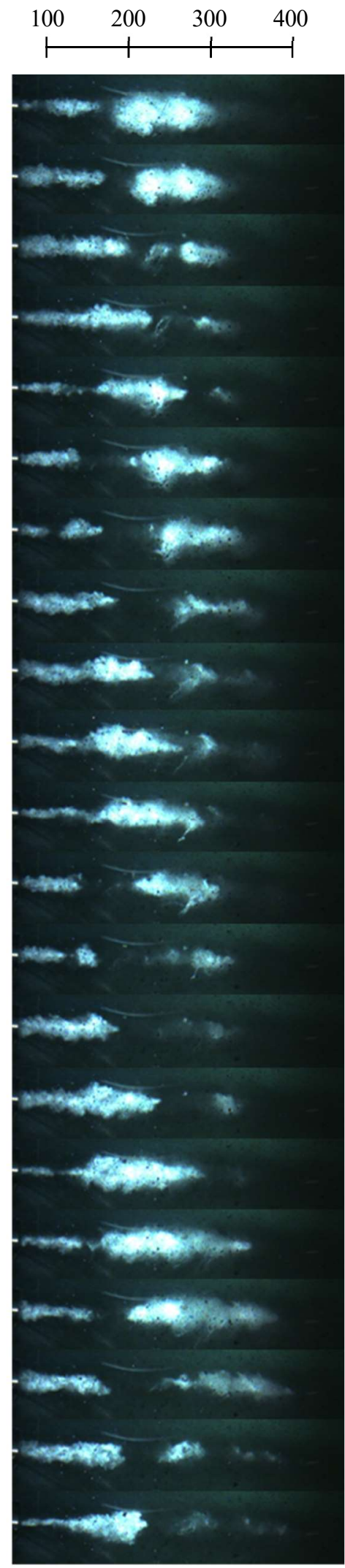

(c) $d_{h}=3.5 \mathrm{~mm}$

Fig. 6 Appearance of cavitation clouds taken with the high-speed video camera. The tip of the guide pipe is visible at the left end of the image. Common to the conditions of each water flow holes, cavitation cloud shedding from guide pipe started at approximately $t=0,4.0,8.8,12.8 \mathrm{~ms}$. The shedding frequency $f_{\text {shedd }}$ can be estimated to be about 200 to $250 \mathrm{~Hz}$. Also, under the condition that there is no holes in (a), the sizes of the cavitation clouds are relatively irregular. 


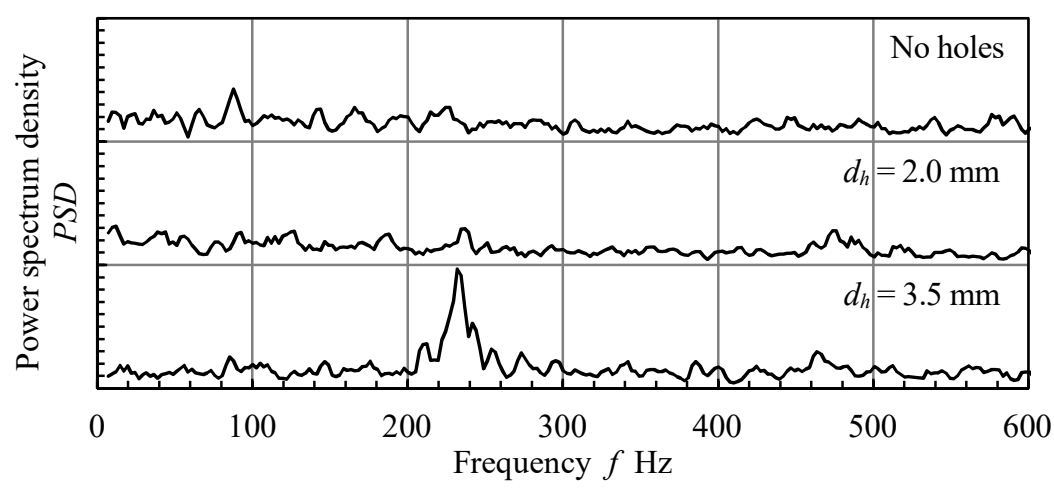

Fig. 7 Power spectrum density obtained by FFT of the photo brightness for about $0.4 \mathrm{~s}(s=120 \sim 158.4 \mathrm{~mm})$. The frequency resolution of FFT was about $2.4 \mathrm{~Hz}$. The moving average of 3 points was applied to obtain the peak frequency roughly. While the dominant frequency is unclear in the nozzle without water flow holes and the nozzle having water flow holes of $d_{h}=2.0$ $\mathrm{mm}$, the dominant frequency is seen at about $230 \mathrm{~Hz}$ in the nozzle having water flow holes of $d_{h}=3.5 \mathrm{~mm}$.

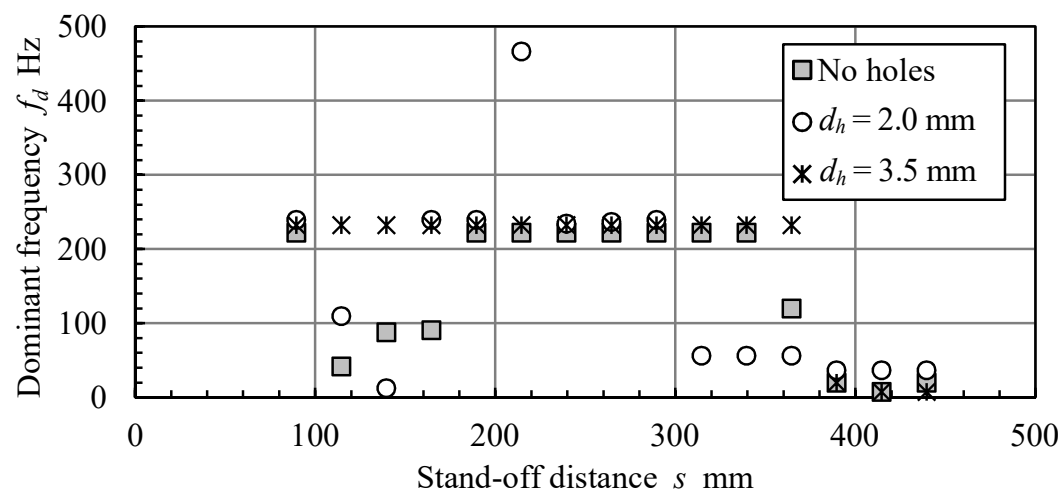

Fig. 8 The dominant frequency $f_{d}$ at each stand-off distance $s$. In the range of $s<300 \mathrm{~mm}$, the dominant frequency are stable at $f_{d}=222.2 \mathrm{~Hz}$ in the nozzle without water flow holes, $f_{d}=239.8 \mathrm{~Hz}$ in the nozzle with water flow holes of $d_{h}=2.0 \mathrm{~mm}$, and $f_{d}=231.9 \mathrm{~Hz}$ in the nozzle with water flow holes of $d_{h}=3.5 \mathrm{~mm}$. This frequency indicates the shedding frequency of the cavitation clouds $f_{\text {shedd }}$, which roughly matches the frequency shown in Fig. 6. Based on $f_{\text {shedd }}$ of the nozzle without water flow holes, $f_{\text {shedd }}$ is increased by $7.7 \%$ in the nozzle with water flow holes of $d_{h}=2.0 \mathrm{~mm}$ and by $4.4 \%$ in the nozzle with water flow holes of $d_{h}=3.5 \mathrm{~mm}$. Since this increase rate of $f_{\text {shedd }}$ is largely different from the increase rate of $\Delta m_{\max }$ shown in Fig. 3, it can be judged that the increase of the shedding frequency does not lead to the increase of the mass loss. At $s>300 \mathrm{~mm}, f_{d}$ drops to below $120 \mathrm{~Hz}$ depending on the water flow holes condition. This indicates that the cavitation clouds are difficult to reach to $s>300 \mathrm{~mm}$.

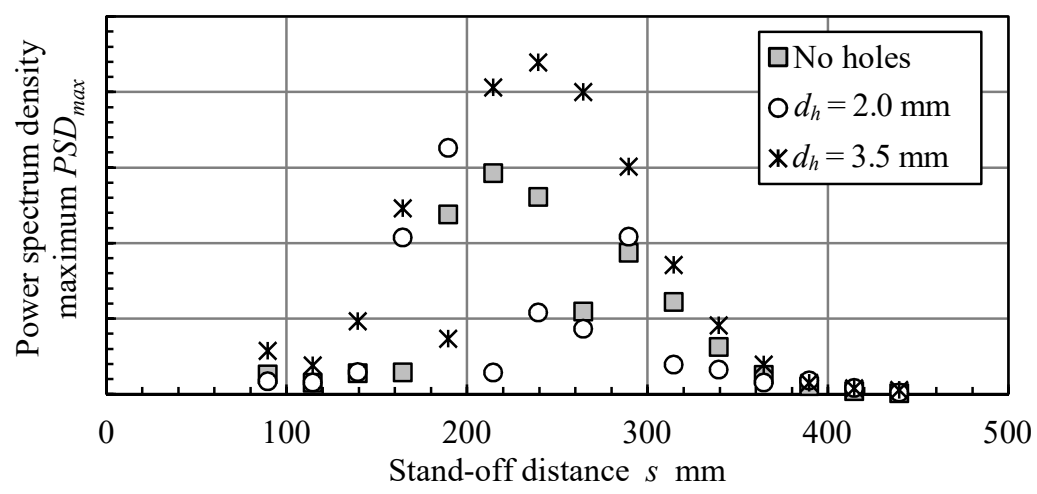

Fig. 9 The power spectrum density of the shedding frequency $f_{\text {shedd }}$ obtained by Fig. 8 . The power spectral density of $d_{h}=3.5$ $\mathrm{mm}$ is larger than the other conditions in most of the stand-off distances for which frequency analysis was performed. Therefore, it can be judged that the shedding frequency under the condition of $d_{h}=3.5 \mathrm{~mm}$ is the most stable. It is presumed that this is because the flow of the main generation space of cavitation bubbles is stabilized as a result of the stable filling flow being formed by the water flow holes. 
ンドオフ距離において,$d_{h}=3.5 \mathrm{~mm}$ のパワースペクトル密度が比較的大きい. これより, $d_{h}=3.5 \mathrm{~mm}$ の通水穴 を有するノズルの放出周波数が最も安定していると判断できる．この要因として，通水穴の作用により，ノズル 出口部へのキャビテーション核を含む水が安定的に供給された結果, キャビテーション主生成場の流れが安定し たことが考えられる，一方，通水穴の無いノズルでは，ガイドパイプ先端の開口部からの充填プロセスとなり， ノズル内に下流方向のキャビテーション噴流と逆方向の充填流が混在することになる．特に，空間容積が小さい ノズルプレート出口の円筒空間では，逆方向の流れが近接するため，流れ場が不安定になり易いと考えられる. 気泡雲の様相を捉えた図 6 の結果を踏まえると, キャビテーション気泡生成場の不安定化は, 気泡雲の放出周波 数と成長規模の不安定化を招く可能性が高いといえる.

\section{$3 \cdot 3$ キャビテーション気泡雲の流速と幅}

高速度ビデオカメラで撮影した画像から得られた，キャビテーション気泡雲の流速 $U$ を図 10 に，気泡雲の幅 $w$ を図 11 に示す．流速は，25 周期分の画像を用いて，気泡雲が長さ $60 \mathrm{~mm}$ を移動するのに要した時間から算出 した．スタンドオフ距離 $s \geqq 300 \mathrm{~mm}$ では，気泡雲が途中で消滅することがあったが，その場合の流速は $0 \mathrm{~m} / \mathrm{s}$ とした. 気泡雲の幅 $w$ は, 約 $0.4 \mathrm{~s}$ 間の画像から輝度が 1 位から 5 位の 5 枚の画像を抜き取り, エッジ処理後に 測定した值の平均値とした。図 10, 11 において, プロットは平均值，バーは標準偏差を表す.

図 10 は，キャビテーション気泡雲が下流に進むほど，流速 $U$ が減少することを示している. $s \leqq 300 \mathrm{~mm}$ は，通水穴の有無と大きさに関わらず，全条件で流速が同程度である. 図 3 の壊食試験において，同一の最適ス タンドオフ距離 $s_{\text {opt }}$ が得られた要因には, この流速がほぼ等しいことが挙げられる. $s=400 \mathrm{~mm}$ では, 通水穴を 有するノズルの方が，通水穴の無いノズルよりも流速 Uが速いことがわかる．この結果は，通水穴を有するノズ ルの方が， $s=400 \mathrm{~mm}$ に到達前に消滅する気泡雲が少ないことに起因する. 流速算出時に用いた 25 周期の気泡 雲中， $s=400 \mathrm{~mm}$ に到達前に消滅した気泡雲の割合は，通水穴の無いノズルでは $76 \%$ ，通水穴径 $d_{h}=2.0 \mathrm{~mm}$ で は $56 \%, d_{h}=3.5 \mathrm{~mm}$ では $64 \%$ であった. 通水穴の作用で強化された随伴流により, キャビテーション気泡雲の 直進性が向上した結果，到達距離，すなわちキャビテーション長さ（Soyama and Lichtarowicz, 1996）が長距離化 したと推測する.

キャビテーション気泡雲の幅 $w$ を示寸図 11 では，全通水穴条件においてピークが存在する. このピークは, 下流に進行するにつれて気泡雲が拡大し, その後減速を伴い, 崩壊していくことによって現れる. ピーク位置は,

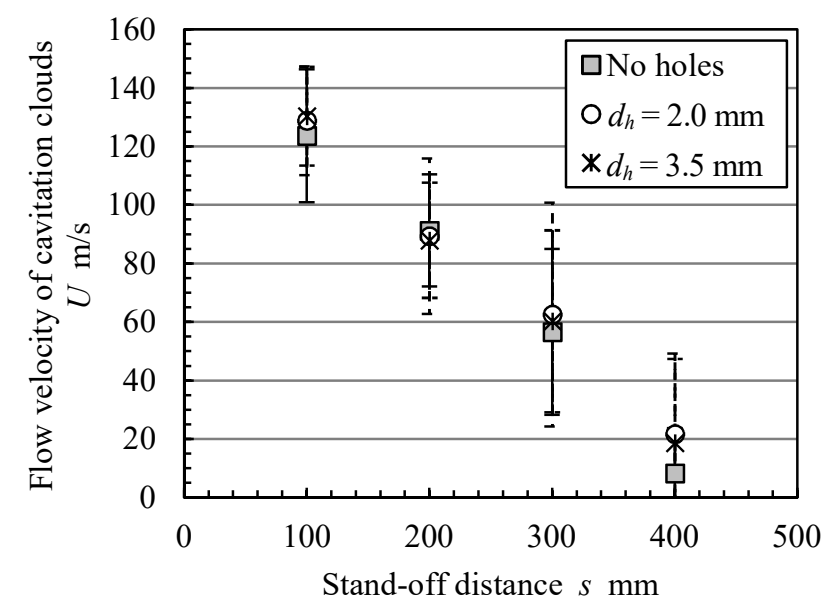

Fig. 10 The velocity of cavitation clouds $U$ at each standoff distance. It is shown that $U$ decreases toward the downstream. At $s \leqq 300 \mathrm{~mm}, U$ is almost the same under all conditions regardless of the presence and diameter of the water flow holes. At $s=400$ $\mathrm{mm}$, the nozzle with the water flow holes has a higher flow velocity $U$ than the nozzle without water flow holes.

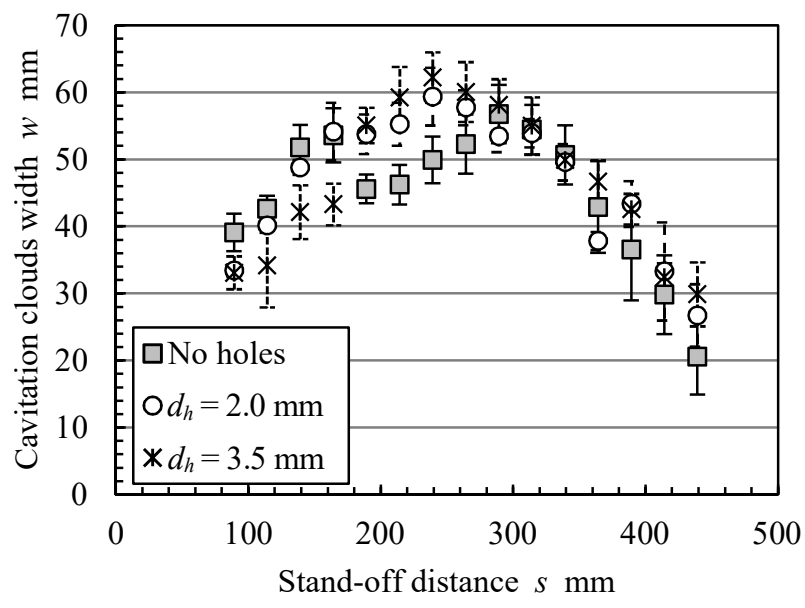

Fig. 11 The width of cavitation clouds $w$ at each stand-off distance. There are peak at all conditions. This peak position substantially matches the cavitating jet aspect of Fig. 6. Under the condition where there are no water flow holes, it is considered that there are two peaks because the straightness of the cavitating jet is low. 
通水穴の無いノズルでは $s=164.2 \mathrm{~mm}$ と $289.2 \mathrm{~mm}$ の 2 箇所，通水穴径 $d_{h}=2.0,3.5 \mathrm{~mm}$ のノズルでは $s=239.2$ $\mathrm{mm}$ の 1 箇所である。これは，図 6 に示した噴流の様相とおおよそ合致する。通水穴の無いノズルにおいて，2 つのピークが存在する要因には，他条件と比較して噴流の直進性が劣ることが考えられる．直進性の低い気泡雲 は拡大し易く, 拡大した気泡雲は減速し, 崩壊し易い. そのため, $s=164.2 \mathrm{~mm}$ の 1 つ目のピークは, 拡大した 気泡雲が早期崩壊したことによって生じたピークといえる. $s=289.2 \mathrm{~mm}$ の 2 目のピークは，噴流中心付近の 直進性の高い気泡雲が進行したことで現れたピークであろう。上記のように，図 10,11 の気泡雲の流速および 幅の観察結果からも，通水穴の作用で随伴流が強化されたことが読み取れる.

\section{$3 \cdot 4$ レイノルズ数}

キャビテーション気泡雲の流速 $U$ とその幅 $w$ を用いて，レイノルズ数 Re の導出を試みた. 既報（Nishimura et al., 2012) では，キャビテーション気泡雲の放出周波数と, 気泡雲の最大幅, 噴射圧力から計算できるノズル出口 での流速を用いて，ストローハル数 $S t$ を算出している． $3 \cdot 2$ 項で述べたように，本報で用いたノズルでは，気泡 雲の放出周波数 $f_{\text {shedd }}$ と最大壊食量 $\Delta m_{\max }$ の相関性が低いことから，ストローハル数よりも，周波数要素を含まな いレイノルズ数での評価が妥当と考えられる.レイノルズ数の算出にあたり，代表速度と代表長さの選択次第で は異なる值が得られる，本報では，通水穴が，キャビテーション気泡雲の特性およびキャビテーション噴流衝突 面上の現象を変化させたことは明白である.これらスタンドオフ距離によって可変する現象を適切に評価するた めには，ノズル部でのパラメータよりも，衝突面近傍でのパラメータを用いることが望ましいと考えられる．し たがって, 高速度ビデオカメラ観察で得られた図 10, 11 の流速 $U$ と幅 $w$ を, 代表速度と代表長さとして適用し た. 流速 $U$ と幅 $w$ によって定義したレイノルズ数 Re を式(1)に示す.

$$
R e=\frac{U \cdot w}{v}
$$

ここで, $v$ は水の動粘性係数である. 流速 $U$ は, 図 10 に示すプロットの二次近似で得られたものを用いた. なお, ストローハル数を算出した結果を付録に記載する.

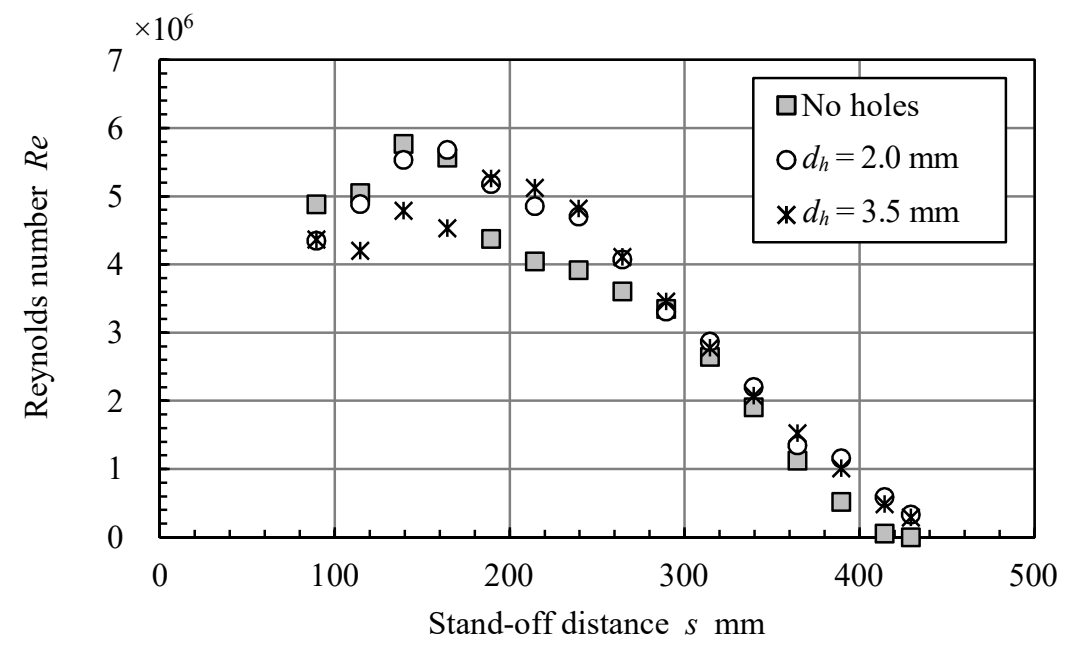

Fig. 12 Reynolds number $R e$ at each stand-off distance $s$. The flow velocity $U$ and the width $w$ shown in Figs. 10 and 11 were applied to the representative velocity and the representative length. The maximum value is shown near $s=150 \mathrm{~mm}$ under all water flow holes conditions. This $s$ substantially matches the $s_{\text {opt }}$ obtained by the erosion test. This indicates that there is an optimal value for the product of flow velocity and width. When the flow velocity is high, that is, when the stand-off distance is short, the impact of the undeveloped bubble acts because the sufficient time for the growth of the cavitation bubble can not be taken. Therefore, in order to increase the mass loss, it is desirable to break up the bubbles on the downstream side where growth time can be secured. On the other hand, the width of the cavitation clouds affects the impact density on the collision surface. A small width, that is, a high impact density, makes the erosion easy to progress. In terms of the trade-off between bubble growth time and impact density, it is assumed that sopt was obtained near the Reynolds number maximum. 
図 12 に, スタンドオフ距離 $s$ とレイノズル数 $R e$ の関係を示す. 全通水穴条件において, $s_{\text {opt }}=150 \mathrm{~mm}$ の最適 スタンドオフ距離近傍でレイノルズ数 Re がピークをとることがわかる.これは，気泡雲の流速と幅の積に最適 值が存在し得ることを示唆している. 流速が大, すなわちスタンドオフ距離が短い場合, キャビテーション気泡 が成長できる十分な時間（加藤，2016）を確保できないため，未発達な気泡の衝撃力が作用することになる．ゆ えに，壊食量の増加を助長するには，気泡の成長時間を確保できる下流側で気泡が崩壊することが望ましい。一 方，気泡雲の幅は，衝突面上での衝撃密度に影響する。幅が小，すなわち衝撃密度が大であるほど壊食の進行が 促進される. 上記, 気泡の衝撃力と衝撃密度のトレードオフの観点から, レイノルズ数のピーク近傍で, 壊食量 のピーク值が得られたと推測する.

\section{4. 結 言}

キャビテーション気泡主生成場への安定かつ連続的な充填プロセスの構築を目的とし, キャビテーション噴流 ノズルのノズルスロート出口に，穴径 $d_{h}=2.0$ および $3.5 \mathrm{~mm}$ の通水穴を設けた. キャビテーション噴流の加工能 力の評価のため, 本ノズルと通水穴の無いノズルとでJIS A1050P の壊食試験を実施し, 壊食量を比較した. また, ノズルから噴射されるキャビテーション気泡雲の特性を把握するために，キャビテーション噴流を高速度ビデオ カメラで撮影した。得られた結果の要約を以下に示す.

（1）通水穴径の大きなノズルほど，単位面積当たりの壊食量が増加した. 通水穴の作用で強化された随伴流 により，試験片上のせき止め圧が上昇した結果，次の 2 つ効果が生じたと考えられる. 1 つ目は，壊 食面積の縮小に伴うキャビテーション気泡の衝撃密度の増加，2つ目は，キャビテーション気泡の崩壊 衝撃力の増大である.

（2）通水穴の無いノズルと比較して，通水穴を有するノズルの気泡雲の放出周波数は 4.4〜 7.7\%増加した. これに対し，最適スタンドオフ距離における壊食量の増加率は 16.0～34.1\%であった. 壊食量の増加率 と比較して放出周波数の増加率が小さいため, 壊食量増加の支配因子は放出周波数の増加ではないと判 断できる.

（3）通水穴径の大きなノズルほど, 気泡雲の放出周波数と成長規模が安定する. キャビテーション気泡主生 成場へのキャビテーション核を含む流れの安定供給が，キャビテーション気泡の生成・成長プロセスの 安定化をもたらしたと推測する.

(4) 高速度ビデオカメラ観察で得られた気泡雲の流速と幅から算出したレイノルズ数は, 壊食試験における 最適スタンドオフ距離近傍で極大值を示した.

付 録

式(2)を用いて，各スタンドオフ距離におけるストローハル数 $S t$ を算出した結果を図 13 に示す.

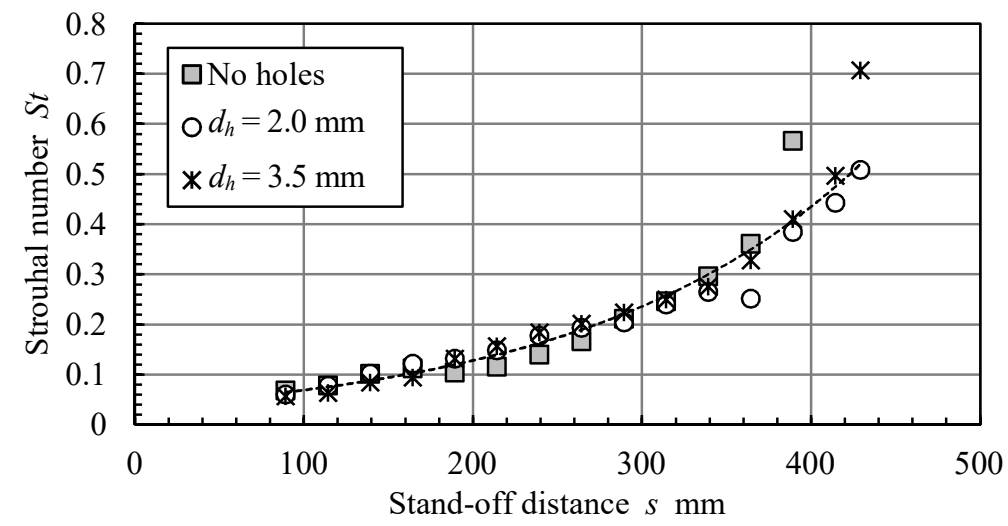

Fig. 13 Strouhal number at each stand-off distance. Most of the plots of the conditions of each water flow holes are located on the same curve. The exponential approximation of this curve is $S t=0.038 \mathrm{e}^{0.006 s}$, which is represented by the curve in the figure. For reference, the Strouhal number for the optimum stand-off distance $s_{\text {opt }}=150 \mathrm{~mm}$ in the erosion test is 0.093 . 


$$
S t=\frac{f_{\text {shedd }} \cdot w}{U}
$$

$f_{\text {shedd }}, w ， U$ は，それぞれ図 8，11，10 から得られたキャビテーション気泡雲の放出周波数，幅，流速である.

図 13 から，ストローハル数には単調増加の傾向が見られる. 各通水穴条件のプロットは，大部分が同一曲線上 に位置していることがわかる．この曲線を指数近似すると，近似式は $S t=0.038 \mathrm{e}^{0.006 s}$ となり，図中の曲線で表され る. 参考までに, 図 3 の壊食試験における最適スタンドオフ距離 $s_{\text {opt }}=150 \mathrm{~mm}$ のストローハル数を算出すると, 0.093 となる.

\section{文献}

ASTM Designation G134-17, Standard test method for erosion of solid materials by cavitating liquid jet, Annual book of ASTM Standards (2017).

平野克彦, 榎本邦夫, 林栄策, 黒沢孝一, SUS304 鋼の耐食性および疲労強度に及ぼすウォータージェットピーニ ングの影響, 材料, Vol. 45, No. 7 (1996), pp. 740-745.

Kamisaka, H. and Soyama, H., Periodical shedding of cavitation cloud induced by a cavitating jet, Proceedings of $23 \mathrm{rd}$ International Conference on Water Jetting (2018), pp. 111-123.

上坂洋雄, 祖山均, 水中高速水噴流を用いた機械的表面改質における噴射圧力の影響, 噴流工学, Vol. 33 , No. 2 (2018), pp. 4-10.

加藤洋治，新版キャビテーションー基礎と最近の進歩一，森北出版 (2016), pp. 75-76.

熊谷直輝, 祖山均, キャビテーション噴流の加工能力に及ぼすノズルスロート長さの影響, 噴流工学, Vol. 32, No. 2 (2016), pp. 25-32.

Nishimura, S., Takakuwa, O. and Soyama, H., Similarity law on shedding frequency of cavitation cloud induced by a cavitating jet, Journal of Fluid Science and Technology, Vol. 7, No. 3 (2012), pp. 405-420.

Sato, K., Taguchi, Y. and Hayashi, S., High speed observation of periodic cavity behavior in a convergent-divergent nozzle for cavitating water jet, Journal of Flow Control, Measurement \& Visualization, Vol. 1 (2013), pp. 102-107.

Soyama, H., Enhancing the aggressive intensity of a cavitating jet by means of the nozzle outlet geometry, Transactions of the ASME, Journal of Fluids Engineering, Vol .133, No .3 (2011), pp .101301-1-11.

Soyama, H., Enhancing the aggressive intensity of a cavitating jet by introducing a cavitator and a guide pipe, Journal of Fluid Science and Technology, Vol. 9, No. 1 (2014), pp .1-12.

Soyama, H., Key factors and applications of cavitation peening, International Journal of Peening Science and Technology, Vol. 1 (2017), pp. 3-60.

Soyama, H., Comparison between the improvements made to the fatigue strength of stainless steel by cavitation peening, water jet peening, shot peening and laser peening, Journal of Materials Processing Technology, Vol. 269 (2019), pp. 65-78.

Soyama, H. and Lichtarowicz, A., Cavitating jets (Similarity correlations), 噴流工学, Vol.13, No.2 (1996), pp.9-19.

祖山均, 西澤登, ノズル出口形状によるキャビテーション噴流まわりの衝撃力の強力化, 混相流研究の進展, Vol. 4 (2009), pp. 77-85.

Soyama, H., Saito, K. and Saka, M., Improvement of fatigue strength of aluminum alloy by cavitation shotless peening, Journal of Engineering Materials and Technology, Vol. 124, No. 2 (2002), pp. 135-139.

Soyama, H., Yamauchi, Y., Adachi, Y., Sato, K., Shindo, T. and Oba, R., High-speed observations of the cavitation cloud around a high-speed submerged water-jet, JSME International Journal Series B Fluids and Thermal Engineering, Vol. 38, No. 2 (1995), pp. 245-251.

祖山均, 山内由章, 井小萩利明, 大場利三郎, 佐藤一教, 進藤丈典, 大島亮一郎, 高速水中水噴流による顕著なピ 一ニング効果ーステンレス鋼の残留応力改善一，噴流工学, Vol. 13, No. 1 (1996), pp. 25-32.

浦直哉, 杉本康弘, 佐藤恵一, キャビテーティングノズルにおける非定常クラウドキャビテーション挙動（ノズル 拡大角の影響），日本機械学会北陸信越支部第 55 期総会・講演会講演論文集, Vol. 55 (2018). 


\section{References}

ASTM Designation G134-17, Standard test method for erosion of solid materials by cavitating liquid jet, Annual book of ASTM Standards (2017).

Hirano, K., Enomoto, K., Hayashi, E. and Kurosawa, K., Effect of water jet peening on corrosion resistance and fatigue strength of type 304 stainless steel, Journal of the Society of Materials Science, Japan, Vol.45, No.7 (1996), pp.740-745 (in Japanese).

Kamisaka, H. and Soyama, H., Periodical shedding of cavitation cloud induced by a cavitating jet, Proceedings of 23 rd International Conference on Water Jetting (2018), pp. 111-123.

Kamisaka, H. and Soyama, H., Effect of injection pressure on mechanical surface treatment using a submergedwater jet, Journal of jet flow engineering, Vol. 33, No. 2 (2018), pp. 4-10 (in Japanese).

Kato, H., Shin-ban Cavitation - Kiso to saikin no shinpo -, Morikita shuppan (2016), pp. 75-76 (in Japanese).

Kumagaya, N. and Soyama, H., Effect of nozzle throat length on aggressive intensity of a cavitating jet, Journal of jet flow engineering, Vol. 32, No. 2 (2016), pp. 25-32 (in Japanese).

Nishimura, S., Takakuwa, O. and Soyama, H., Similarity law on shedding frequency of cavitation cloud induced by a cavitating jet, Journal of Fluid Science and Technology, Vol. 7, No. 3 (2012), pp. 405-420.

Sato, K., Taguchi, Y. and Hayashi, S., High speed observation of periodic cavity behavior in a convergent-divergent nozzle for cavitating water jet, Journal of Flow Control, Measurement \& Visualization, Vol. 1 (2013), pp. 102-107.

Soyama, H., Enhancing the aggressive intensity of a cavitating jet by means of the nozzle outlet geometry, Transactions of the ASME, Journal of Fluids Engineering, Vol. 133, No. 3 (2011), pp. 101301-1-11.

Soyama, H., Enhancing the aggressive intensity of a cavitating jet by introducing a cavitator and a guide pipe, Journal of Fluid Science and Technology, Vol. 9, No. 1 (2014), pp. 1-12.

Soyama, H., Key factors and applications of cavitation peening, International Journal of Peening Science and Technology, Vol. 1 (2017), pp. 3-60.

Soyama, H., Comparison between the improvements made to the fatigue strength of stainless steel by cavitation peening, water jet peening, shot peening and laser peening, Journal of Materials Processing Technology, Vol. 269 (2019), pp. 65-78.

Soyama, H. and Lichtarowicz, A., Cavitating jets (Similarity correlations), Journal of Jet Flow Engineering, Vol. 13, No. 2 (1996), pp. 9-19.

Soyama, H. and Nishizawa, K., Enhancement of impact force around a cavitating jet by changing with nozzle outlet geometry, Progress in Multiphase Flow Research, Vol. 4 (2009), pp. 77-85 (in Japanese).

Soyama, H., Saito, K. and Saka, M., Improvement of fatigue strength of aluminum alloy by cavitation shotless peening, Journal of Engineering Materials and Technology, Vol. 124, No. 2 (2002), pp. 135-139.

Soyama, H., Yamauchi, Y., Adachi, Y., Sato, K., Shindo, T. and Oba, R., High-speed observations of the cavitation cloud around a high-speed submerged water-jet, JSME International Journal Series B Fluids and Thermal Engineering, Vol. 38, No. 2 (1995), pp. 245-251.

Soyama, H., Yamauchi, Y., Ikohagi, T., Oba, R., Sato, K., Shindo, T. and Oshima, R., Marked peening effects of highspeed submerged-water-jets - residual stress change on SUS304 - , Journal of Jet Flow Engineering, Vol. 13, No. 1 (1996), pp. 25-32 (in Japanese).

Ura, N., Sugimoto, Y. and Sato, K., Behavior of unsteady cloud cavitation in a cavitating nozzle (Effects of divergent angle), The Japan Society of Mechanical Engineers Hokuriku Shin-etsu branch 55th General Meeting \& Lecture Proceedings, Vol. 55 (2018) (in Japanese). 